\title{
Goals Structuring based on Value-Focused Thinking methodology: Creating alternatives for sustainability in the urban mobility
}

\author{
ALVES, F.B.M - Technological Institute of Aeronautics - Brazil \\ SOUSA JÚNIOR, W.C. - Technological Institute of Aeronautics - Brazil
}

\begin{abstract}
The greatest force in combating climate change is in the hands of cities. The management of urban mobility, focused on improving the fluidity of cars, ends up increasing the demand for more road space and consequently the social and environmental impacts. Thus, this article aims to structure and understand the problem of urban mobility and to propose strategic actions that lead to the promotion of its sustainability. The importance of this study is to support the local government in the definition of a compromise solution, in a medium and long term perspective, seeking to guarantee citizens access to quality transport services and the joint participation of society in the construction of more sustainable cities. The research is based on the Value-Focused Thinking approach to identify decision problems, specify objectives and create alternatives. The application identified critical factors with greatest impact and define a set of alternatives. As a result, 13 key alternatives were selected to achieve sustainable urban mobility. In this way, the product of this research contributes to the 2030 Agenda for the development of sustainable cities, thus being able to effectively serve as a contribution to the formulation of future sustainability policies.
\end{abstract}

\section{Keywords}

Sustainability, Climate Change, Urban Mobility, Value-Focused Thinking (VFT)

\section{Introduction}

The greatest force in combating climate change is in the hands of cities. Currently, 55\% of the world's population lives in urban areas and this proportion is expected to increase to $70 \%$ by 2050 (UN, 2019). The way these people will live in cities in 2050 is related to the choices being made today and the demand for transport is one of them. The management of urban mobility, centred on improving the fluidity of cars, ends up increasing the demand for more road space and, consequently, increasing the social and environmental impacts, highlighting the increase in greenhouse gas emissions.

The latest report on the physical sciences explaining past, present and future climate change released by the Intergovernmental Panel on Climate Change (IPCC) presents the latest projections for temperature rise, advances in attributing extreme weather events to climate change and greater risks of reaching tipping points where significant impacts become irreversible. Two findings are especially relevant, according to the IPCC, the world could reach $1.5^{\circ} \mathrm{C}$ of warming in the next two decades but there is still a small window of opportunity to limit warming to $1.5^{\circ} \mathrm{C}$ by 2100 , but it will be necessary to act decisively 
and very quickly to contain emissions in this decade, as well as to zero net emissions of greenhouse gases by 2050 .

Within this context, it is increasingly necessary to establish guidelines for sustainable urban mobility, one of whose purposes is to encourage the circulation of active modes (pedestrian and bicycle) and the use of mass transport.

There is an ongoing need to develop new action strategies and to build a new paradigm for urban mobility that is not limited only to access to means of transport. Instead, more environmental, economic, social and behavioral issues are involved in solving the problem, that becomes complex.

Thus, this article seeks to answer the following research questions for this study: (i) how should transport sustainability be treated in a structured way? (ii) What are the objectives that should be considered in the context of decision analysis and how should they be measured? (iii) how to propose eligible alternatives to public policies aimed at the real needs of its inhabitants, without conflicts of interest?

In recent years, studies have been carried out with the aim of contributing more to urban mobility in the context of sustainable and resilient cities. However, research carried out during the development of this article did not find previous studies that took into account the structuring in the decision-making process for the generation of sustainable urban mobility alternatives. This, therefore, is one of the reasons that led the authors to investigate this topic.

This study is part of a larger project that seeks to create an index to assess and monitor the sustainability of transport in a city.

Therefore, the main objective of the study is to structure the problem of urban mobility in Brazilian cities by 1) understanding the fundamental values of the main actors of the problem who deal daily with adverse mobility conditions in the city studied; 2 ) explore and analyse these values to create possible alternatives that can lead to the implementation of sustainability in transport. Thus, this study aims to obtain a better understanding of this problem, using the Value-Focused Thinking - VFT methodology for this purpose. VFT is used to structure these goals and create alternatives in a structured way. This allows for the emergence of new ideas that will contribute to the use of transport and more sustainable practices in urban displacement. A case study in a medium to large Brazilian city is presented.

This article is organized as follows: section 1 presents the article; Section 2 reviews the literature on sustainability in the context of mobility; Section 3 presents the research method; Section 4 presents methodological proposal, section 5 presents Application and section 6 discusses the results obtained; Section 7 presents the conclusions of this research.

\section{Literature review}

This section provides a brief review of the literature on sustainability in urban mobility and tools used to analyse mobility.

\subsection{Sustainability in the context of Urban Mobility}

The first questions about sustainable development originated from the discussion around environmental problems and the expectation of a potential depletion of essential natural resources for humans. The alarm about the depletion of these resources came from the first report to the Club of Rome, The Limits to Growth (MEADOWS et al, 1972). During the 1990s, new concepts about global warming emerged, challenging the traditional development model and highlighting the emergence of issues related to sustainability, including the effects of urbanization on climate change (LONDE and MENDES, 2014; 
GUERRA et al., 2016). Since then, the growing concern for the future of the planet has sought to develop more sustainable projects, especially in transport issues.

The demand for mobility, and the growing dependence on private vehicles for urban travel in particular, is currently one of the main points in the debate on sustainable urban development, as it is responsible for several social, economic and environmental impacts (CAMAGNI, GIBELLI and RIGAMONTI, 2002).

The lack of tools developed to measure mobility within the urban context is one of the several difficulties encountered by planners and the public administration in planning this aspect of cities (SILVA and ROMERO, 2015).

However, the use of indicators has proved useful to understand, analyse and measure the transport system and urban mobility.

According to Gomes et al. (2010), indicators and indexes can serve a set of applications according to the objectives under study. Among the applications, the following stand out: resource allocation, location classification, compliance with standards, trend analysis, public information and scientific investigation. Indicators are obtained from a set of data (parameters or variables) and, when used in any evaluation or analysis method, generate sub-indices or indexes whose values serve as tools to aid decision-making and analysis of current situations or future.

But even though sustainable mobility indicators are available in national and international literature, some aspects related to these tools have not yet been properly explored. These aspects mainly refer to the construction of indices that aggregate variables related to climate change, and that enable an analysis both in an integrated, global index, and sectored in specific fields.

In the studies analysed (BANISTER et al, 2000; JEON, 2005; LITMAN, 2008; COSTA, 2008; MACHADO, 2010; MOBILIZE, 2011), it is noted that there are still gaps to be studied when referring to studies of nonmotorized, pedestrians and cyclists. The assessment of the urban transport road infrastructure itself is also rarely mentioned in the studies analysed. It was also observed that for the proposal and choice of indicators to be made efficiently, the opinion of the actors involved in the problem is fundamental, since it is based on the importance of identifying the weights of the indicators in the very place where one is seeking to act.

In this way, structuring the Mobility problem becomes an extremely important factor, and several methods of the Soft Operational Research area can be applied to this.

\section{Methods of Structuring Problems in Decision-Making}

This section provides a brief explanation of the problem structuring methods that are most evident in the tools used in the study.

\subsection{The Soft Operational Survey}

The Problem Structuring Methods belong to the movement called Soft Operational Research (PO Soft for short) or Practical Operational Research (VIDAL, 2006). PO Soft emerged during the 1970s as a result of dissatisfaction of the limitations of Traditional Operational Research. Known as PO Hard, it is restricted to well-structured problems, like problems for which a consensual formulation can be affirmed in terms of performance measures, restrictions and relationships, through which action produces consequences (MINGERS \& ROSENHEAD, 2004).

At PO Soft, the operational researcher acts as a facilitator, since all the actors actively participate in structuring and solving the problem. According to Mingers and Rosenhead (2004), the PSMs allow 
participants to clarify their difficult situation, converge on a potential mutual problem or some topic within it, and agree on commitments that will be resolved at least partially.

There are several methods of structuring problems and as an example they are cited: SODA (Strategic Options Development Analysis), which uses as main tool the construction of cognitive maps; SSM (Soft Systems Methodology), which uses the rich figure as the main tool; SCA (Strategic Choice Approach), which uses decision areas as the main tool. The three tools that will be used in the study are highlighted below.

\subsection{Stakeholder analysis}

An actor is understood to be anyone who directly or indirectly participates in or is influenced by the process, including specialists, decision makers, workers, users, consumers, traders, etc. In the scope of public policies, the actors and their behaviors represent the nucleus of any possible theoretical model (BOERBOOM \& FERRETTI, 2014; DENTE, 2014). The actors make the actions capable of influencing the decision-making results and they do so because they pursue goals in relation to the problem and its possible solution, or in relation to their interaction with other actors (DENTE, 2014). In particular, any actor with an interest in the decisionmaking process, whether directly affecting or being affected by its resolution, including experts and the public, is called a stakeholder (FERRETTI, 2016).

Stakeholder analysis is recognized as a trend that aims to combine the objectives for the solution of the problem, with the external environment and the demands of stakeholders that highlight the values, principles and processes when raising important aspects for decision making.

There are several techniques for mapping stakeholders and the most used is the power / interest matrix proposed by Mendelow (1981). Ackermann and Eden (2011), define four categories of stakeholders, based on the power / interest relation (see Figure 1), separating the participants in the process and their influences on the problem.

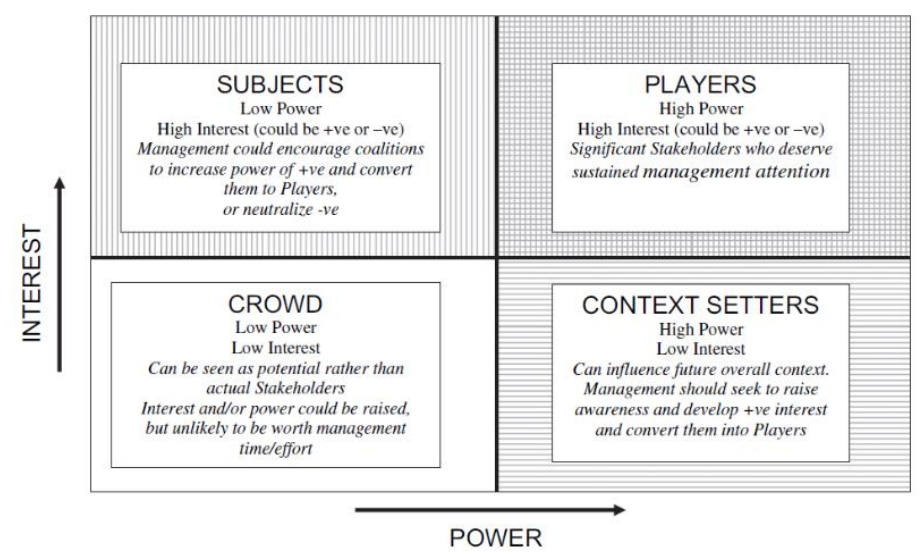

Figure 1- Stakeholder Power-Interest Matrix. Source: Ackermann and Eden (2011).

Identifying and studying the stakeholders involved in a decision problem is particularly important in the domain of public decision making, as key stakeholders can be invited to participate in brainstorming sessions where cognitive mapping techniques can be used to identify and discuss the issues and, goals to be pursued in a more systemic and interdisciplinary approach (FERRETTI, 2016).

\subsection{Value-Focused Thinking - VFT}

The Value Focused Thinking - VFT approach is very common to deal with complex problems, it was proposed by Keeney (1992) in which it basically consists of two activities: first deciding what you want 
and then figuring out how to achieve it. The VFT is based on values that, according to Keeney (1996), should be an engine of this process, since they are essential in day-to-day decision-making.

According to Keeney (1996), the VFT's principle is to identify desirable decision opportunities and create alternatives to reach the goal, based on the decision maker's values, in a proactive way Morais et al. (2013) point out that the VFT provides a systematic approach to structuring complex decisions and subsequent analysis and, therefore, contributes important insights for decision making. The adoption of values improves the decision-making process, in which three aspects characterize the objectives: 1) the decision context; 2) an object; 3) a preference direction ( de Almeida et al., 2015 ).

Thus, the VFT suggests procedures designed to structure goals and values in an organized manner. For Keeney (1996), it is first necessary to compile a list of initial goals and then categorize and structure them logically as means or ends. After the structuring phase, alternatives based on these objectives are created and, finally, the worthwhile decision opportunities are identified.

The use of this methodology allowed Decision Makers, in different application contexts, to identify important objectives of the problems, and revealed objectives that had not been identified until then. This methodology also allows the Decision Maker to identify, build and understand the relationships between objectives, in a logical way, since these are presented in a means-end network.

\section{Methodological Proposal}

This section presents the methodological steps of the study.

The steps that comprise the method are shown in Figure 2. The methodology was supported by the framework adopted by Franco and Montibeller (2011); Abuabara et al. (2019) for interventions based on Multi-Criteria Decision Analysis (MCDA) methods. In this framework, the intervention takes place in an initial phase called "divergent phase". At this stage, uncertainties emerge regarding the desired values and objectives as well as their respective attributes. The second phase, called convergent, consists of creating alternatives and defining the criteria for the consequent evaluation of the performance of the alternatives. At the end of this phase, a sensitivity analysis and a recommendation to decision-makers are carried out. For the article we will stick only to the results of the Decision Problem Structuring, the divergent phase of the decision process. 


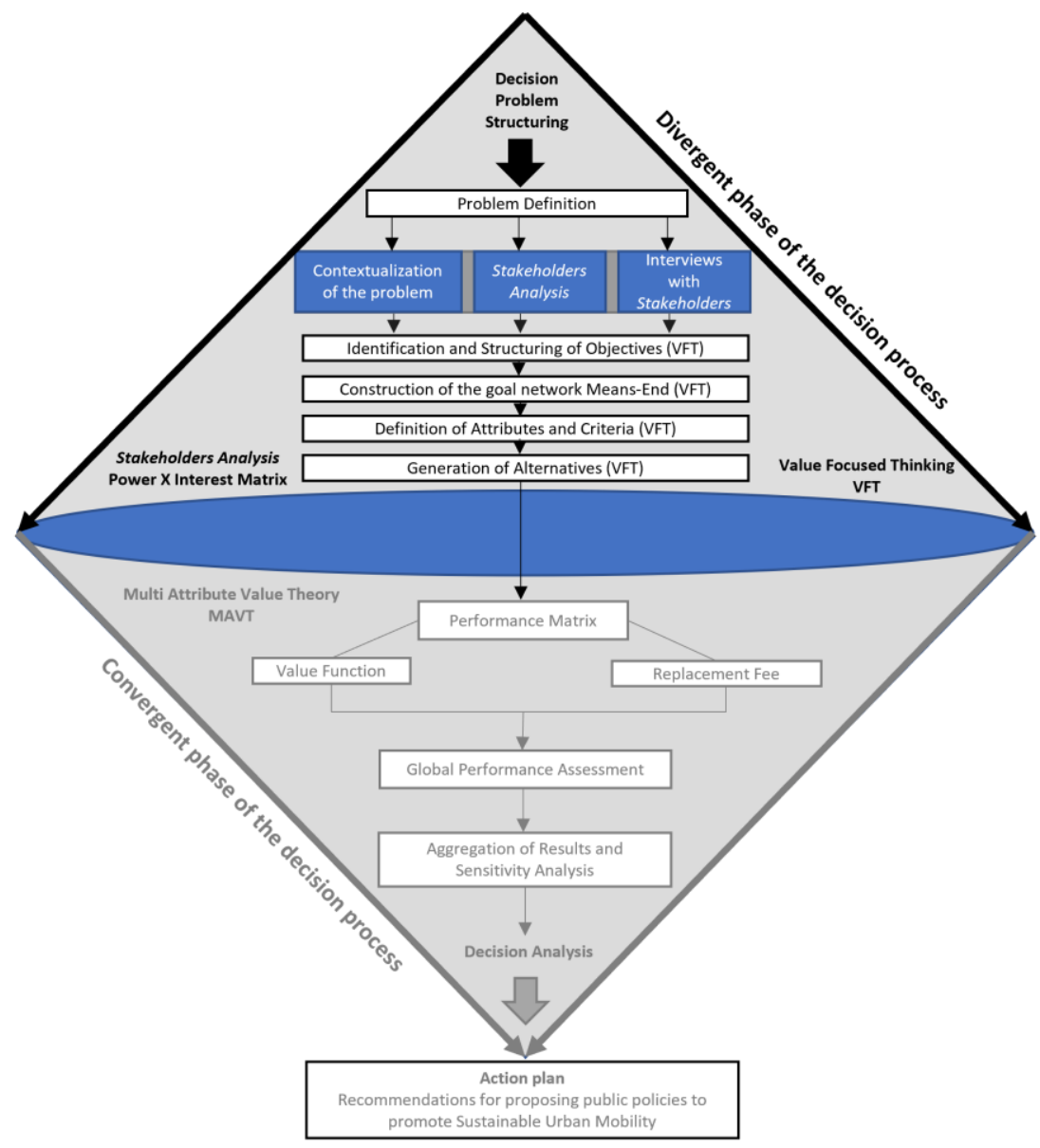

Figure 2 - Decision Making Process. Source: Adapted from Abuabara et al. (2019).

\section{Application - Decision Problem Structuring}

This section presents the application of problem structuring methods for decision making.

\subsection{Problem Definition}

To start implementing the VFT, it is important to provide the decision-making framework that consists of the subject context and the fundamental objectives. The problem context defines the set of alternatives appropriate for consideration in a specific decision situation, while the alternatives are the means by which the fundamental value is found. It is important to remember that at the heart of any decision problem is the desire to avoid adverse effects and find the desirable ones. (Keeney, 1992).

\subsubsection{Problem Contextualization}

The city of São José dos Campos was chosen to illustrate the case study, as it is a city that still has deficits in infrastructure and transportation planning, accessibility, urban planning and an expressive number of individual motorized transport being used, leading to urban mobility problems.

Located on the state of São Paulo, Brazil, it is a large city, with an estimated 713,943 inhabitants in 2018 and a total area of approximately $1,100 \mathrm{~km}^{2}$, in which $353.9 \mathrm{~km}^{2}$ are in urban perimeter (Figure 3), São José dos Campos is the 6th city in the state of São Paulo in population size and the 26th considering the whole country. (IBGE 2018). 


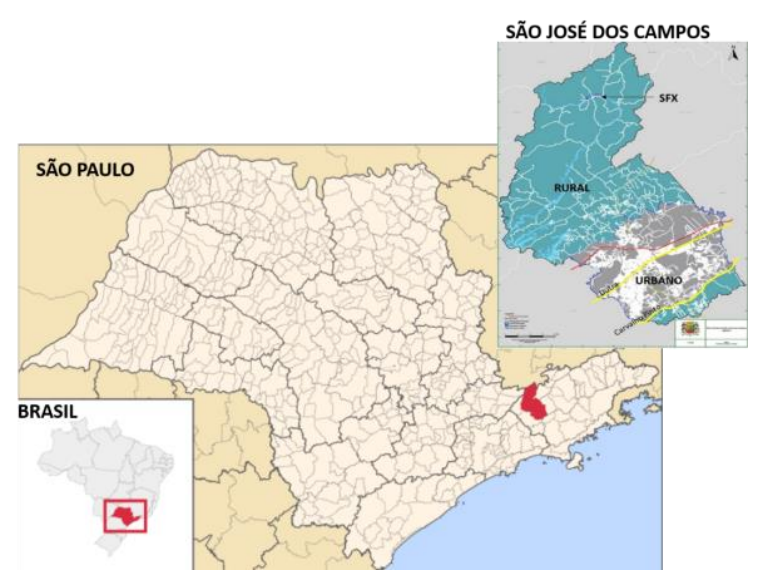

Figure 3 -Location map of the study area. Source: PDDI - LC 612/2018 adapted by the author (2020).

With the growth of the vehicle fleet in recent years, São José dos Campos presents problems in its urban mobility with intense traffic during peak hours, especially when population is leaving school and work. The bus system is still flawed, with high capacity at peak times and low capacity throughout the day making the waiting time for the collective to exceeds what the user wants. Some bus stops do not have adequate infrastructure and are positioned in remote locations. The city's cycle network has been expanding every year, today it has $96 \mathrm{~km}$ of bike lanes and is expected to grow to $157 \mathrm{~km}$ by the year 2021 , but adherence to this mode is still small, only $3 \%$ of the total trips in the city is done by bicycle.

Environmental pollution is another very worrying factor in the municipality, a survey conducted in the city in 2017 showed an increase in the amount of pollutants in the air, five types of pollutants were found, all of which are harmful to health and the environment. The amount of these pollutants increased from 10.3 thousand tons per year to 10.6 thousand, an increase of 3.19\%. Such values correspond to 50\% more air pollution than the maximum limit recommended by the World Health Organization (WHO). The amount of inhalable particles suspended in the air has also increased in the city. Added to the weather conditions due to severe droughts in the region, the worsening of air quality becomes a serious problem. (CETESB 2018).

\subsubsection{Stakeholder analysis - Power-Interest Matrix}

Based on Ackermann and Eden (2011), who define four categories of stakeholders, according to the interest and power relation, it was defined which people would participate in the process of building cognitive maps. The survey of stakeholders interested in achieving sustainable urban mobility in the city of São José dos Campos is highlighted in Table 1 next.

Table 1. Selected Stakeholders. Source: The authors

\begin{tabular}{|l|l|l|l|l|l|}
\hline ID & Stakeholders & Profession & Type & Interest & Power \\
\hline \hline 1 & Former Secretary of Transport & Engineer / Politician & Technician & Hight \\
\hline 2 & $\begin{array}{l}\text { Former Employee of the Urban Planning } \\
\text { Secretariat }\end{array}$ & $\begin{array}{l}\text { Architect and Urban Planner / Master in } \\
\text { Urban Planning }\end{array}$ & Technician & Hight \\
\hline 3 & Cyclists' representative & Journalist and Master in Urban Planning & Special Interest / Technician & Hight & Low \\
\hline 4 & Representative of people with disabilities & Retiree & Special Interest & Hight & Low \\
\hline 5 & Worker - Public transport user & Concierge Assistant & Special Interest & Hight & Low \\
\hline 6 & University student & Architecture and Urbanism Student & Special Interest & Hight & Low \\
\hline
\end{tabular}

\subsubsection{Interview with Stakeholders}

The interviews were conducted individually, recorded and had an average duration of 40 to 60 minutes. A pre-established script of questions was used to guide the interviews, but the researchers were free to adapt the questions to the given situation, change the order of topics or ask other questions. The 
interview script was designed to have twenty questions that, in some specific cases, were adapted to fit the intervening professional attributions. To facilitate the interview script, it was divided into two parts. The first part to help emerge the values, individual views of each respondent about the problem and the second part to try to extract the objectives.

In this study, we reached the validity of the VFT approach, based on the subjective judgments of experts, of a non-statistical nature. According to Lucko and Rojas (2010), the strongest way to establish facial validity is to involve specialists in the subject before, during or throughout the research. In the present study, experts were involved throughout the research. Also according to Lucko and Rojas (2010), at least two iterations are necessary: the first to collect data through interviews or questionnaires, for which the questions are compiled by the researcher; as for the second iteration, in which the same experts receive all the data and provide new comments. In this process, a consensus can be generated. These iterations were performed to collect the data necessary for the VFT and for the consequent validation of the obtained results.

\subsection{Identification and Structuring of Objectives (VFT)}

To identify and structure the objectives, the first step was to define the strategic objective. Initially, the strategic objective of the research was defined as "How to achieve Sustainable Urban Mobility?". From a detailed analysis of the interviews and having identified the fundamental objectives and means-goals, it was concluded that the objective established by the participating parties was not the one initially defined, but that of "Proposing Actions that can be implemented in the cities that aim at sustainable urban mobility".

After consolidating the lists of the objectives of each actor in the process resulting from the interviews, the fundamental objectives were defined. They were structured considering the three dimensions of Sustainability: Environmental, Social and Economic. Thus, the fundamental objectives, designed to address the strategic research problem, were structured as shown in Table 2.

Table 2. Hierarchy of fundamental objectives. Source: The authors

\begin{tabular}{|r|l|}
\hline 1 & Enviromental \\
\hline 1.1 & Reduce and rationalize fuel consumption \\
\hline 1.2 & Use renewable sources / clean energy \\
\hline 1.4 & Reduce CO$^{2}$ emission \\
\hline 1.5 & Reduce the number of hospitalizations for respiratory diseases \\
\hline 1.6 & Maximize the city's cycling network \\
\hline 1.7 & Encourage bicycle use \\
\hline 1.8 & Increase the number of paracycles in the city \\
\hline 2 & Social \\
\hline 2.1 & Promote transport intermodality \\
\hline 2.2 & Maximize accessibility \\
\hline 2.3 & Minimize traffic accidents \\
\hline 2.4 & Improve traffic education \\
\hline 2.5 & Implement traffic education in schools \\
\hline 2.6 & Integrate the departments of urban planning, environment and mobility \\
\hline 2.7 & Involve the population in decision making \\
\hline 2.8 & Prioritize sustainable means of transport \\
\hline 3 & Economic \\
\hline 3.1 & Reduce public transport fares \\
\hline 3.2 & Optimize travel \\
\hline 3.3 & Minimize spending on transportation in family income \\
\hline 3.4 & Reduce travel time \\
\hline
\end{tabular}




\subsection{Construction of the Middle-End Goals Network (VFT)}

It is important to distinguish between "fundamental objectives" and "means objectives". Fundamental objectives are about ends in specific decision content, while means-objectives are the ways to achieve these ends. It is important to bear in mind that ends and means are context dependent. Meansobjectives can suggest alternatives that enable fundamental objectives to be achieved.

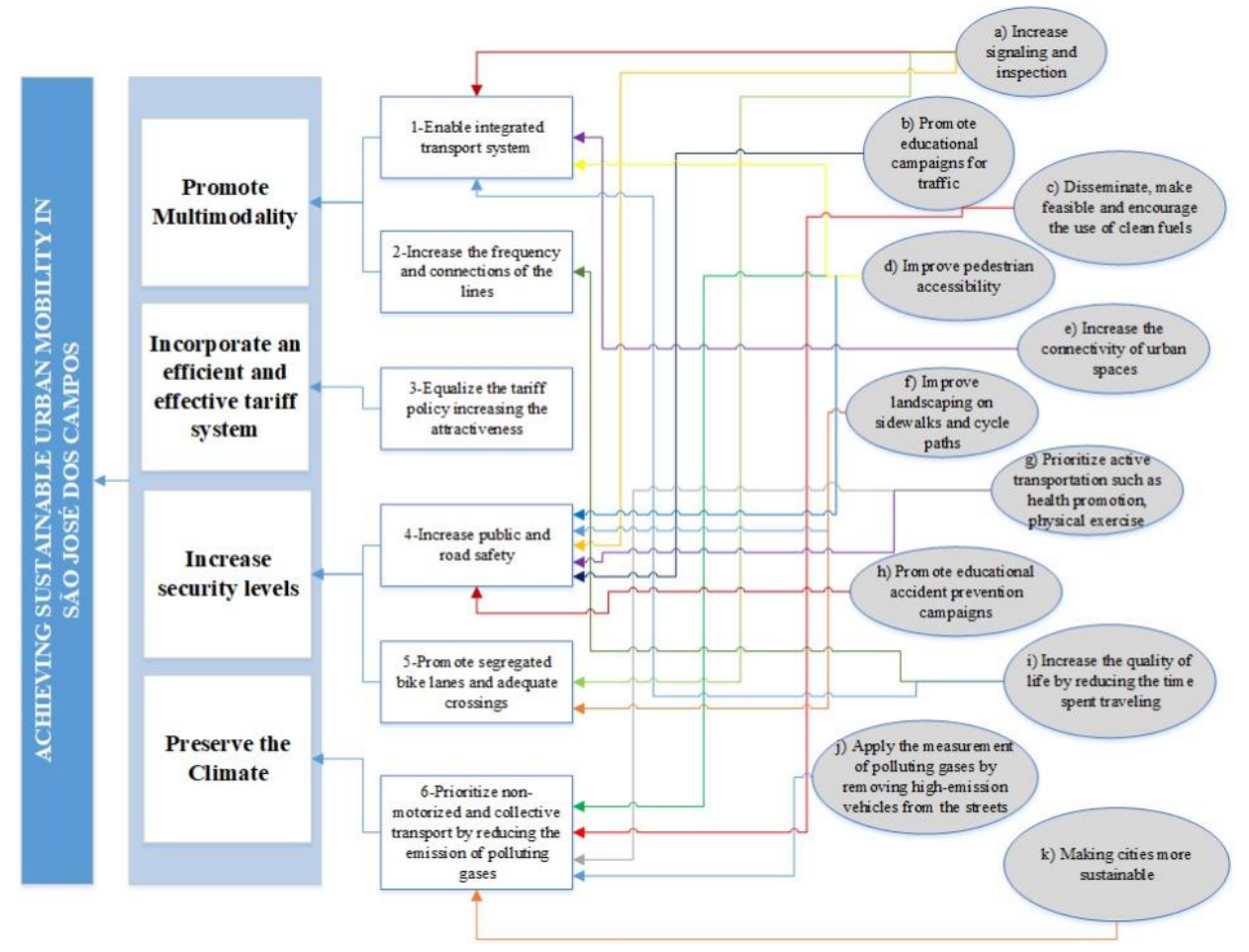

Figure 4.Demonstrates the means-goals network of this study. Source: The authors.

Regarding the validation of this network, we achieved face validity, since it is based on subjective judgments of experts, gathered by the iterations carried out. In these iterations, the list of objectives for each expert was obtained, redundancies analyzed and the objectives structured (fundamental and means objectives). The network was constructed and after several iterations, with the experts receiving the same network and providing new comments, a consensus was reached and the network validated.

\subsection{Definition of Attributes and Criteria (VFT)}

The attributes and criteria of the fundamental objectives are listed in Table 3. These attributes were identified from the literature consulted and interviews with experts, thus establishing the best way to measure them. 
Table 3. Attributes of fundamental goals. Source: The authors

\begin{tabular}{|c|c|c|c|}
\hline \multicolumn{2}{|c|}{ Criterion } & \multirow[t]{2}{*}{ Descriptors (Unit of measure) } & \multirow[t]{2}{*}{ Objective } \\
\hline $1 \mathrm{E}$ & 1 Enviromental & & \\
\hline $1.1 \mathrm{~F}$ & Fuel consumption & L/Inhabitant /Year & Minimize \\
\hline $1.2 \mathrm{C}$ & Uso de energia limpa & $\%$ & Maximize \\
\hline 1.3 C & $\mathrm{CO}^{2}$ emissions & $10^{3} \mathrm{t} /$ year & Minimize \\
\hline $1.4 \mathrm{~F}$ & Population exposed to traffic noise & $\%$ & Minimize \\
\hline $1.5 \mathrm{~F}$ & Respiratory diseases & number of assistance / year & Minimize \\
\hline $1.6^{\mathrm{E}}$ & Bike path extension & $\%$, degree of connectivity & Maximize \\
\hline $1.7 \mathrm{~F}$ & Frota de bicicletas & bicycles/100 inhabitants & Maximize \\
\hline $1.8 \mathrm{E}$ & Estacionamento para bicicletas & $\%$ & Maximize \\
\hline 25 & \multicolumn{3}{|l|}{ Social } \\
\hline 2.1[ & Diversity of modes of transport & Number & Maximize \\
\hline 2.2 & Calçadas acessíveis & $\%$ & Maximize \\
\hline \begin{tabular}{l|l}
2.3 & 1 \\
\end{tabular} & Traffic-accidents & Deaths in traffic accidents $/ 100,000$ inhabitants & Minimize \\
\hline 2.4 C & Campanhas educativas trânsito seguro & Yes/No & Maximize \\
\hline $2.5 \mathrm{E}$ & Education for Transit in Schools & Yes/No & Maximize \\
\hline 2.6 F & Planejamento Urbano, Ambiental e de Transportes Integrado & Yes/No & Maximize \\
\hline $2.7 \mathrm{P}$ & Participação popular na tomada de decisão & Degree of participation & Maximize \\
\hline 2.81 & Urban Mobility Plan & Yes/No & Maximize \\
\hline \multicolumn{4}{|c|}{\begin{tabular}{l|l|}
3 & Economic \\
\end{tabular}} \\
\hline 3.1 T & Tarifa - Discounts and gratuities & $\%$ & Maximize \\
\hline $3.2^{\mathrm{V}}$ & Vehicle occupancy rate & Passengers / mileage & Maximize \\
\hline 3.35 & Spending on transportation & $\%$ (Average monthly income / simple urban bus fare) & Minimize \\
\hline $3.4 \quad \mathrm{~T}$ & Tempo médio de viagem & minutes in transport / day & Minimize \\
\hline
\end{tabular}

Based on identified values, some additional alternatives can be identified in addition to those already in the problem under analysis. These new alternatives are often not clear at the beginning of the process, but they become desirable and feasible within the framework of established goals and values.

\subsection{Generation of alternatives (VFT)}

Creating alternatives for a given decision problem is not a simple process (Morais et al., 2013). Thus, the alternatives that arise, in most cases, are those already known by those involved in the problem.

Some alternatives that can be applied in order to promote sustainable mobility, such as: $\mathbf{x x x}$, were generated based on the analysis of structured objectives rooted in the values of the actors in the construction process who were interviewed.

These alternatives are presented in Table 4 with the aim of contributing to improvements associated with transport sustainability. 
Table 4.Alternative actions that can be implemented in the city aimed at sustainable urban mobility. Source: The authors

\begin{tabular}{|r|l|}
\hline & Environmental Aspects \\
\hline 1 & Encourage active modes of transport on small daily journeys \\
\hline 2 & Investment in new, more eco-efficient bus technologies, reducing energy consumption and noise \\
\hline 3 & Invest in increasing the entire cycling infrastructure in the city, considering paracycles, changing rooms, workshops and integration with buses. \\
\hline & Social Aspects \\
\hline 4 & Promote the integration of urban planning policies and actions with the transport policy and actions. \\
\hline 5 & $\begin{array}{l}\text { Make modal integration feasible (on foot, bicycle and bus), encourage the use of collective and sustainable transport in routine routes, favor } \\
\text { population density in the areas of public transport corridors, expand routes for sustainable modes reducing parking spaces. }\end{array}$ \\
\hline 6 & Increase the level of public safety and reduce the number of accidents with appropriate infrastructure for each modal and inspection. \\
\hline 7 & Improve dialogue between municipal secretariats involved in the process, so that decision-making is joint. \\
\hline 8 & Promote permanent workshops covering social, economic and environmental aspects related to the transport system. \\
\hline 9 & Requalify public roads and walkways for users (accessibility). \\
\hline 10 & Involve, listen to the population in decision-making through surveys, meetings with councils. \\
\hline & Economic Aspects \\
\hline 11 & Equalize the tariff policy for the system's financial balance as an attractiveness mechanism. \\
\hline 12 & To thicken road corridors by investing in medium to large-capacity transport modes. \\
\hline 13 & Plan adjustments to existing infrastructure considering budget limitations. \\
\hline
\end{tabular}

Having defined the alternatives to be considered in the problem under study, the process of choosing which should be used is conducted using the Multi-Criteria Decision Analysis (MCDA) methods, with the objective of producing recommendations and even the formulation of future public policies. The result of this step (which is not within the scope of this article) significantly contributes to defining the amount of resources that will be invested in the selected alternatives, what the priorities will be, and always taking into account existing resource constraints.

\section{Results}

From the problem structuring, it was possible to understand the problematic situation by describing the decision context to which the model will be applied. The stakeholder analysis raised the main actors of the problem, including all categories and hierarchical levels, in order to guarantee the representativeness of all users and service providers.

As a result of the analysis of these interviews, it was possible to identify a list of objectives for each actor in the process. The initially proposed strategic objective was redefined. The redundancies were analysed as was the meaning of each objective for which a comparison was made with the other participants in order to structure the objectives, define the fundamental objectives and establish the hierarchy of the fundamental objectives. Some of the objectives extracted from the interviews were considered as halfgoals. After the researchers involved performed several iterations, the network was built with the meansgoals. This network underwent some adjustments after the experts who participated in the interviews analysed it, and after these adjustments were made, they validated them. Attributes for measuring the fundamental objectives were defined based on the literature and the knowledge of experts. Finally, some actions were created by analysing the objectives that were defined, first individually and after that, combining them.

Therefore, this process had several interactions that included collecting data with the experts, compiling the researchers' responses and returning this to the experts until a consensus was reached on the objectives, the network of objectives, attributes and alternative actions.

\section{Conclusion}

Urban transport consumes a considerable fraction of natural resources and energy around the world. To address this issue effectively, the problem needs to be analysed in a structured way. Therefore, the application of the VFT was fundamental for structuring the problem. This was done considering the ideas, opinions and proposals of experts and actors on the problem, thus allowing a better assessment of the 
context for decision-making. It also created alternatives as a starting point to identify opportunities with regard to decision making.

It is possible to conclude that it is necessary to know how to apply the good practices related to mobility in order to change the current scenario. These good practices already exist and are widespread worldwide, although some specialists claim that this application is only successful if it comes to meet the intrinsic characteristics (historical, cultural, climatic..) of the region under analysis. Therefore, the development of sustainability policies in urban transport is optimized when the operational researcher and the stakeholders manage to understand and structure the problem of urban mobility, identifying regionally which are the most relevant criteria for the analysis of mobility.

\section{Acknowledgment}

To the Coordination of Improvement of Higher Education Personnel - CAPES. This study was financed in part by the Coordenação de Aperfeiçoamento de Pessoal de Nível Superior - Brasil (CAPES) - Finance Code 001"

\section{References}

Abuabara. L , Caceres A.P, and Cromwell T.B. (2019), 'Os valores e comportamento dos consumidores no mercado brasileiro de café-em-cápsulas: promoção da economia circular', International Journal of Production Research, 57:23, 72697288, DOI: 10.1080/00207543.2019.1629664

Ackermann F.; Eden, C.(2011), 'Strategic Management of Stakeholders: theory and practice.' Long Range Planning, v. 44, p. 179-196.

De Almeida, A. T., Cavalcante, C. A. V., Alencar, M. H., Ferreira, R. J. P., de Almeida-Filho, A. T., \& Garcez, T. V. (2015). 'Modelos multicritérios e multiobjetivos para análise de decisão de risco, confiabilidade e manutenção' (Vol. 231). Nova lorque: Springer International Publishing.

Banister, D.; Stead D.; Steen, P.; Akerman, J.; Dreborg, K.; Nijikamp, P.; Tappeser R.S. (2000), 'Targets for Sustainability Mobility', European Transport Policy and Sustainable Mobility, cap.8, pp119, Spon Press.

Boerboom, L. , \& Ferretti, V. (2014). 'Actor network theory perspective on a forestry decision support system design'. Scandinavian Journal of Forest Research, 29 , 84-95 .

Camagni, R., Gibelli, M.C., Rigamonti, P. (2002), 'Urban mobility and urban form: the social and environmental costs of diferente patterns of urban expansion', Ecological Economics, n. 40.

Costa, M.S. (2008) 'Um Índice de Mobilidade Urbana Sustentável'. Tese (Doutorado). Escola de Engenharia de São Carlos, Universidade de São Paulo. USP, São Carlos. 314 p.

Cetesb (2018) 'Qualidade do ar no estado de São Paulo 2017'. Disponível em https://cetesb.sp.gov.br/ar/publicacoes-relatorios/. Público acesso em 10 de setembro de 2019.

Dente, B. (2014). 'Understanding policy decisions' . PoliMI SpringerBriefs

Franco, L. A.; Montibeller, G. (2010), 'Facilitated modelling in operational research'. European Journal of Operational Research, v. 205, n. 3, p. 489-500, 2010. 
Ferretti, V. (2016). 'From stakeholders analysis to cognitive mapping and Multi-Attribute Value Theory: An integrated approach for policy support'. European Journal of Operational Research v. 253 /524-541, 2016.

Gomes, L. F. A. M.; Rangel, L. A. D. E Jerônimo, R.L. (2010). 'A study of professional mobility in a large corporation through cognitive mapping.' Pesquisa Operacional, v. 30, p. 331-344, 2010.

Guerra, J.B.S.O.A., Ribeiro, J.M.P., Fernandez, F., Bailey, C., Barbosa, S.B., Neiva, S.S. (2016) 'The adoption of strategies for sustainable cities: a comparative study between Newcastle and Florianópolis focused on urban mobility', Journal of Cleaner Production, n. 113

IBGE. (2018) 'Censo Demográfico - Características Gerais da População'. Resultados da Amostra. Disponível em http://www.ibge.gov.br/. Público acesso em 02 de agosto de 2020.

Jeon, C.M. (2005) 'Incorporating sustainability into transportation planning and decision making: definitions, performance measures, and evaluation'. Tese (Ph.D. in the School of Civil and Environmental Engineering Georgia Institute of Technology. Atlanta, EUA. 225p.

Keeney, R. L.(1992). Value-Focused Thinking. Massachusetts: Harvard University Press.

Keeney, R. L. (1996), 'Value-focused thinking: Identifying decision opportunities and creating alternatives.' European Journal of operational Research, v. 92, n. 3, p. 537-549.

Litman, T. (2008) 'Developing Indicators for Comprehensive and Sustainable Transport Planning, Transportation'. Transportation Research Board, Research Record 2017.

Londe, P.R., Mendes, P.C. (2014) 'A Influência das Áreas Verdes na Qualidade de Vida Urbana', Revista Brasileira de Geografia Médica e da Saúde, v. 10, n. 18, pp. 264-272.

Lucko, G., \& Rojas, E.M. (2010). 'Validação da pesquisa: Desafios e oportunidades no domínio da construção'. Revista de engenharia e gestão da construção civil, 136(1), 127-135.

Machado. L (2010) 'Índice de Mobilidade Sustentável para avaliar a qualidade de vida urbana Estudo de caso Região Metropolitana de Porto Alegre - RMPA.' Dissertação de Mestrado. PósGraduação em Planejamento Urbano e Regional da Universidade Federal do Rio Grande do Sul. 172 p.

Meadows, D. H.; Meadows, D. L.; Randers, J.; Behrens lii, W. W. (1972) The limits to growth \& a report for The Club of Rome's project on the predicament of mankind. New York: Universe Books.

Mendelow, A. (1981). 'Environmental scanning: The impact of stakeholder concept'. In Proceedings of the second international conference on information systems, December 1981, Cambridge, Mass .

Mingers, J.; Rosenhead, J. (2004), 'Problem structuring methods in action'. European Journal of Operational Research, v.152, p.530-554.

Mobilize. (2011), ‘Estudo Mobilize 2011: Diagnóstico da Mobilidade Urbana Sustentável e Capitais Brasileiras'. São Paulo: Associação Abaporu.

Morais, D.C., Alencar, L. H., Costa, A. P., \& Keeney, R. L. (2013). 'Usando o pensamento focado no valor no Brasil'. Pesquisa Operacional, 33,73-88.

Silva, G., Romero, M. (2015) 'Sustentabilidade urbana aplicada: Análise dos processos de dispersão, densidade e uso e ocupação do solo para a cidade de Cuiabá, Estado de Mato Grosso, Brasi', EURE, v. 41, n. 122 , pp. 209- 237.

United Nations, Department of Economic and Social Affairs, Population Division (2019). "World Population Prospects 2019: Highlights" (ST/ESA/SER.A/423). 

sustainability in the urban mobility

Vidal, R.V.V. (2006), 'Operational Research: a multidisciplinary field’. Pesquisa Operacional, v.26, n.1, p.69-90. 